\title{
Program Langit Biru : Kontribusi Kebijakan Pengendalian Pencemaran Udara Kota terhadap Penurunan Penyakit Pernapasan pada Anak
}

\section{Laila Fitria}

\begin{abstract}
Abstrak
Pencemaran udara perkotaan yang berdampak buruk terhadap kesehatan masyarakat sering dikaitkan dengan $\mathrm{PM}_{10}$, $\mathrm{NO}_{2}$, dan ozon, polutan reaktif yang memicu kerusakan jaringan dalam saluran napas melalui mekanisme stres oksidatif dan inflamasi saluran napas. Pajanan jangka panjang polutan tersebut berpengaruh terhadap gangguan pernapasan, penurunan fungsi paru, asma, serta penyakit sistem pernapasan kronik lain seperti penyakit paru-paru obstruktif kronik. Program Langit Biru merupakan salah satu upaya mengurangi pencemaran udara dari sektor transportasi yang dicanangkan sejak tahun 1996. Hingga kini, kontribusi Program Langit Biru terhadap penurunan kasus gangguan pernapasan pada anak belum dapat diperkirakan, antara lain disebabkan oleh karena pelaksanaan program melalui kegiatan riil yang baru terwujud beberapa tahun setelah dicanangkan, serta berbagai kendala lainnya. Padahal, beberapa penelitian di negara lain menunjukkan bahwa pengendalian pencemaran udara dapat memberikan kontribusi yang cukup signifikan bagi penurunan kasus-kasus penyakit pernapasan pada anak. Oleh karena itu, agar terwujud kualitas udara yang aman bagi kesehatan, dibutuhkan dukungan dan peran yang lebih besar dari pemerintah, pelaksana program, dan masyarakat.
\end{abstract}

Kata kunci : Pencemaran udara, program langit biru

\begin{abstract}
Urban air pollution that have negative impact on public health is frequently related to PM10, NO2, and ozone, the reactive pollutants that could trigger internal tissue of respiratory tract through mechanism of oxidative stress and respiratory tract inflammation. Long term exposure to the pollutant related to respiratory abnormality, lung function, asthma, chronic respiratory disease, and chronic obstructive pulmonary disease. The Blue Sky Program is one measure for reducing air pollutant of transportation sector and has been designed since 1996. Until now, the blue sky program contribution on respiratory track disorder reduction on children has not been predicted yet, due to delay in program implementation and real activities were just been realized years after the program declaration and also due to other constraints. Researches in other countries show that air pollution control contributes significantly to the reduction of respiratory track disease among children. To achieve healthy air quality, bigger support and more active role from government, program manager and public are essentially needed.
\end{abstract}

Key words : Air pollution, blue sky program

Departemen Kesehatan Lingkungan Fakultas Kesehatan Masyarakat Universitas Indonesia, Gd. C Lt. 2 FKM UI, Kampus Baru UI Depok 16424 (e-mail: lailafitria@yahoo.com) 
Pencemaran udara yang terjadi di perkotaan mengakibatkan dampak yang merugikan terhadap kesehatan masyarakat. Suatu studi yang dilakukan Asian Development Bank (ADB) pada tahun 2002 menunjukkan bahwa dampak kesehatan akibat pencemaran udara di Jakarta telah menelan biaya perawatan kesehatan sekitar Rp 1,8 triliun dengan korban utama adalah anak-anak, risiko kematian dini, penurunan produksitivitas kerja, gangguan produksi pertanian dan lain sebagainya. Jika tidak dilakukan pengendalian segera, pada tahun 2005, biaya tersebut diperkirakan dapat meningkat hingga Rp 4,3 triliun. ${ }^{1}$ Meskipun demikian, perhatian pemerintah terhadap upaya pengelolaan udara perkotaan dinilai belum maksimal, antara lain disebabkan oleh koordinasi yang lemah antar instansi pemerintah.

Kelompok masyarakat yang paling parah mengalami dampak akibat pencemaran udara adalah anak-anak khususnya mereka yang berbakat asma yang merupakan kelompok yang sensitif terhadap pajanan polutan udara luar (outdoor air pollutants). Berbagai penelitian yang dilakukan sehubungan dengan dampak polusi udara luar terhadap gangguan kesehatan pada anak memperlihatkan bahwa anak-anak yang tinggal di pemukiman yang dekat dengan jalan raya berisiko lebih tinggi untuk terjadi kasus baru asma, peningkatan gejala asma atau eksaserbasi asma, tingkat absensi sekolah yang lebih tinggi serta tingkat rawat inap di rumah sakit akibat asma yang lebih tinggi. ${ }^{2}$

Proporsi anak-anak terpajan polutan udara luar yang besar dan risiko dampak kesehatan serius yang ditimbulkan, harus menjadi pertimbangan dasar bagi pelaksanaan upaya pengendalian pencemaran udara. Program Langit Biru merupakan salah satu upaya yang dikumandangkan oleh Pemerintah Indonesia untuk mengurangi pencemaran udara, khususnya yang bersumber sektor transportasi. Ada tiga upaya yang dilakukan terhadap pencemaran udara akibat transportasi, meliputi mengganti bahan bakar, mengubah mesin kendaraan, dan memasang alat-alat pembersih polutan pada kendaraan. Sejak program tersebut dicanangkan pada tahun 1996 hingga saat ini, belum diketahui seberapa besar kontribusinya terhadap penurunan dampak kesehatan pada anak-anak, terutama penyakit-penyakit yang terkait dengan gangguan pernapasan.

\section{Pencemaran Udara Luar}

Pencemaran udara luar atau outdoor air pollution sering disebut juga sebagai pencemaran udara ambien. Di daerah perkotaan, sumber utama pencemaran udara luar adalah tingkat kepadatan lalu lintas kendaraan bermotor di jalan raya. Kontribusi pencemaran udara kota oleh lalu lintas diperkirakan sebesar 70\%, sementara sisanya bersumber dari industri, pemukiman (rumah tangga), dan sumber-sumber lain.

Pada tahun 1998 BAPEDAL (Badan Pengendalian Dampak Lingkungan) menetapkan beberapa jenis polutan dengan konsentrasi di udara ambien yang harus selalu dikendalikan, melalui pemantuan Indeks Standar Pencemar Udara (ISPU). Polutan yang termasuk ke dalam ISPU meliputi karbon monoksida (CO), partikulat yang meliputi $\mathrm{PM}_{10}$ dan $\mathrm{PM}_{2,5}$ (partikel berukuran kurang dari 10 mikron dan 2,5 mikron), $\mathrm{NO}_{2}$ (nitrogen dioksida), $\mathrm{SO}_{2}$ (sulfur dioksida), dan Ozon. Tiga di antara kelima polutan tersebut merupakan polutan yang paling banyak diteliti terkait dengan gangguan pernapasan pada anak, meliputi partikulat, nitrogen dioksida, dan ozon. Berikut ini adalah uraian mengenai masing-masing polutan udara tersebut.

\section{Partikulat}

Partikulat (particulate matter) merupakan istilah yang digunakan untuk menggambarkan partikel yang tersuspensi di udara, dapat berupa padatan ataupun cairan, dan merupakan salah satu bentuk polusi yang paling nyata karena dapat tampil dalam bentuk kabut yang menyelimuti kota atau wilayah. Polusi oleh partikel merupakan campuran dari padatan yang berukuran mikroskopik dan droplet cairan yang tersuspensi di udara, yang tersusun dari sejumlah komponen, termasuk zat asam seperti nitrat dan sulfat, bahan kimiawi organik, logam, partikel debu, dan zat yang bersifat alergen (misalnya serbuk sari/pollen ataupun spora kapang). Partikulat memiliki rentang ukuran yang cukup lebar. Ukuran tersebut dikenal sebagai diameter aerodinamik (aerodynamic diameter), yang mengacu pada unit kepadatan dari bentuk partikel dengan sifat aerodinamik yang sama, misalnya kecepatan jatuh. Partikulat yang penting bagi kesehatan masyarakat adalah $\mathrm{PM}_{10}$ dan $\mathrm{PM}_{2,5}$.

$\mathrm{PM}_{10}$ adalah partikulat padat atau cair yang melayang di udara dengan nilai median ukuran diameter aerodinamik kurang dari 10 mikron. $\mathrm{PM}_{10}$ memiliki beberapa nama lain, yaitu inhalable particles, respirable particulate, respirable dust dan inhalable dust. $\mathrm{PM}_{10}$ juga dapat bersifat toksik karena dapat mengandung campuran partikulat jelaga, kondensat asam, garam sulfat, partikel nitrat, ataupun logam-logam berat. Sumber utama $\mathrm{PM}_{10}$ di perkotaan adalah asap kendaraan bermotor. Partikulat ini dapat terhisap ke dalam sistem pernafasan dan menyebabkan gangguan pernafasan dan kerusakan paruparu. $\mathrm{PM}_{10}$ diketahui dapat meningkatkan angka kematian yang disebabkan oleh penyakit jantung dan pernafasan, pada konsentrasi $140 \mu \mathrm{g} / \mathrm{m}^{3}$ dapat menurunkan fungsi paru-paru pada anak-anak, sementara pada konsentrasi $350 \mu \mathrm{g} / \mathrm{m}^{3}$ dapat memperparah kondisi penderita bronkhitis. ${ }^{2}$

$\mathrm{PM}_{2,5}$ merupakan partikulat dengan ukuran diameter kurang dari 2,5 mikron. $\mathrm{PM}_{2,5}$ dihasilkan dari proses 
pembakaran, termasuk asap buangan dari kendaraan bermotor, juga dihasilkan dari reaksi kimia antar berbagai gas seperti sulfur dioksida, nitrogen dioksida, dan VOCs (volatile organic compounds). Partikulat jenis ini dapat berada di atmosfir dalam waktu yang tidak terbatas, serta memiliki kemampuan menyebarkan cahaya sehingga dapat mengakibatkan penurunan jarak pandang. Pada saat ini $\mathrm{PM}_{2,5}$ diyakini sebagai kontributor utama terhadap berbagai dampak kesehatan manusia, oleh karena partikulat tersebut mampu memasuki dan memblokir saluran terkecil yang terdapat di dalam paruparu. Studi-studi kesehatan menunjukkan terdapatnya hubungan yang signifikan antara pajanan $\mathrm{PM}_{2,5}$ dengan kematian dini akibat penyakit jantung ataupun penyakit paru. $\mathrm{PM}_{2,5}$ dapat memperburuk penyakit jantung dan penyakit paru, dan telah dihubungkan dengan beberapa dampak seperti: gejala-gejala kardiovaskular, cardiac arrhytmias, serangan jantung, gejala-gejala gangguan pernapasan, serangan asma, dan bronkitis. Kelompok masyarakat yang rentan terhadap pajanan $\mathrm{PM}_{2,5}$ meliputi mereka yang memiliki riwayat penyakit jantung ataupun penyakit paru, para lanjut usia, dan anak-anak. ${ }^{3}$

Hasil data pemantauan udara ambien di 10 kota besar di Indonesia menunjukan bahwa $\mathrm{PM}_{10}$ merupakan parameter yang paling sering muncul sebagai parameter kritis. $^{2}$

\section{Nitrogen Dioksida}

Nitrogen dioksida merupakan gas berwarna kecoklatan dan bersifat sangat reaktif. Sumber utama $\mathrm{NO}_{2}$ di perkotaan adalah asap kendaraan bermotor. $\mathrm{NO}_{2}$ di udara dapat terurai dengan bantuan sinar matahari sehingga dapat terbentuk ozon. Oksida nitrogen $\left(\mathrm{NO}_{\mathrm{x}}\right)$ adalah kontributor utama smog dan deposisi asam. Nitrogen oksida bereaksi dengan senyawa organik yang volatile membentuk ozon dan oksidan lainnya seperti peroksiasetilnitrat (PAN) di dalam smog fotokimia, dan dengan air hujan menghasilkan asam nitrat dan menyebabkan hujan asam. Smog fotokimia berbahaya bagi kesehatan manusia karena menyebabkan kesulitan bernafas pada penderita asma, batuk-batuk pada anak-anak dan orang tua, dan berbagai gangguan sistem pernafasan, serta menurunkan visibilitas. Oksida nitrogen diproduksi terutama dari proses pembakaran bahan bakar fosil, seperti bensin, batu bara dan gas alam. ${ }^{2}$

\section{Ozon}

Ozon merupakan gas yang terdiri dari tiga atom oksigen. Ozon yang terdapat pada lapisan troposfer ini termasuk ke dalam pencemar sekunder yang terbentuk dari reaksi fotokimia antara oksida nitrogen $\left(\mathrm{NO}_{\mathrm{x}}\right)$ dan hidrokarbon (HC). Ozon bersifat oksidator kuat, oleh karena itu, pencemaran oleh ozon troposferik dapat menyebabkan dampak yang merugikan bagi kesehatan manusia. Laporan Badan Kesehatan Dunia menyatakan konsentrasi ozon yang tinggi $\left(>120 \mu \mathrm{g} / \mathrm{m}^{3}\right)$ selama $8 \mathrm{jam}$ atau lebih dapat menyebabkan serangan jantung dan kematian, atau kunjungan ke rumah sakit karena gangguan pada sistem pernafasan. Pajanan pada konsentrasi 160 $\mu \mathrm{g} / \mathrm{m}^{3}$ selama 6,6 jam dapat menyebabkan gangguan fungsi paru-paru akut pada orang dewasa yang sehat dan pada populasi yang sensitif. ${ }^{2}$

\section{Mekanisme Gangguan Pernapasan}

Pada kondisi normal, saluran napas manusia yang dalam keadaan sehat mampu mengatasi polutan yang masuk bersama udara pernapasan tanpa menyebabkan gangguan yang berarti ataupun dampak jangka panjang. Sedangkan, pada individu yang sensitif, atau pada saat terjadi polusi yang cukup tinggi, polutan dapat berkontribusi terhadap terjadinya peningkatan gejala gangguan pernapasan ataupun penyakit pernapasan. Penelitian menunjukkan dampak kesehatan akibat pajanan polutan, terutama partikulat, tergantung pada sejumlah faktor, antara lain: ukuran partikulat (yang menentukan apakah partikulat dapat menembus masuk ke saluran napas bagian bawah), intensitas dari pajanan, sifat kimiawi dari partikulat dan interaksinya dengan jaringan tubuh manusia, keberadaan kondisi pemicu (khususnya penyakit pada saluran napas), dan faktor meteorologis seperti angin, kelembaban, inversi suhu, hujan, ataupun hujan yang disertai angin ribut dan petir/guruh.

Blumenthal, ${ }^{4}$ dan Koren, ${ }^{5}$ memaparkan mekanisme di dalam tubuh terhadap pajanan polutan udara, khususnya partikulat, dengan uraian berikut ini. Sistem pernapasan merupakan sistem pertahanan tubuh yang terdepan dari pemaparan polutan melalui udara. Luas permukaan saluran pernapasan berkisar antara $80-100 \mathrm{~m}^{2}$, dan meliputi permukaan dari 300 juta alveoli yang merupakan terminal jalan napas. Seorang individu menghirup napas sekitar 10.000 hingga 20.000 liter udara setiap hari, dan setiap satu liter mungkin mengandung jutaan partikel tersuspensi (suspended particles) dan berbagai gas baik yang organik maupun inorganik. Polutan yang masuk bersama udara pernapasan akan mengakibatkan sejumlah reaksi pertahanan tubuh, antara lain batuk, bersin, aktivitas mukosilier, spasme laring, bronkokonstriksi, atau takipneu. Pada saluran trakeobronkial, berbagai partikel yang masuk akan disingkirkan melalui proses sedimentasi dan difusi. Begitu partikel mengendap, akan disingkirkan oleh batuk atau kerja mukosilier atau diabsorbsi oleh darah. Daerah alveoli saluran napas tidak dilapisi dengan silia sehingga partikel-partikel yang mengendap di sana mungkin difagosit dan disingkirkan ke arah epitel bersilia oleh makrofag alveoli.

Sementara itu, pada tingkat seluler, pajanan akut $\mathrm{PM}_{10}, \mathrm{NO}_{2}$, dan ozon melalui udara pernapasan akan mengakibatkan stres oksidatif dan inflamasi saluran per- 
napasan. ${ }^{6}$ Stres oksidatif merupakan suatu kondisi ketidakseimbangan antara proses pembentukan dengan eliminasi radikal bebas. Radikal bebas yang dimaksud meliputi berbagai molekul spesies oksigen reaktif atau reactive oxygen species (ROS) yang dihasilkan sebagai produk sampingan respirasi mitokondrial dalam proses metabolisme normal, juga termasuk radikal bebas yang berasal dari luar tubuh, yang meliputi berbagai jenis polutan, termasuk polutan yang terbawa melalui udara pernapasan. Proses eliminasi radikal bebas dikenal sebagai sistem antioksidan, yang merupakan mekanisme pertahanan untuk mencegah kerusakan sel akibat adanya molekul-molekul radikal bebas. Terjadinya stres oksidatif akan memicu terjadinya kerusakan sel, dan selanjutnya akan mengundang diproduksinya sel-sel radang, sehingga terjadi inflamasi.

Beberapa penelitian membuktikan bahwa $\mathrm{PM}_{10}, \mathrm{NO}_{2}$, dan ozon merupakan polutan udara yang bersifat reaktif dan dapat memicu kerusakan jaringan dalam saluran pernapasan melalui mekanisme stres oksidatif dan inflamasi saluran napas, baik pada penderita asma atau pada individu yang sehat. 7,8 Pada penderita asma, respon inflamasi yang terjadi lebih tinggi daripada individu yang sehat. Pajanan yang intensif dari berbagai polutan tersebut berhubungan dengan berbagai bentuk gangguan pernapasan, penurunan fungsi paru, asma, serta penyakit sistem pernapasan kronik lainnya seperti penyakit paruparu obstruktif kronik. ${ }^{2,9-12}$ Mekanisme yang terjadi adalah, pajanan yang terus-menerus akan menyebabkan terjadinya respon inflamasi yang berulang dan akan memicu kerusakan saluran napas yang permanen.

Anak-anak merupakan kelompok masyarakat yang rentan mengalami dampak kesehatan akibat pajanan polutan udara ambien, oleh karena anak-anak memiliki karakteristik yang rentan. Anak-anak yang masih dalam masa pertumbuhan, sehingga paru-paru dan sistem imun mereka juga sedang berada pada masa perkembangan. Untuk aktivitas bermain, anak-anak lebih banyak berada di luar ruangan, sehingga lebih mungkin terpajan polutan, daripada kelompok dewasa. Selain itu, anak-anak menerima polutan dalam dosis yang relatif lebih tinggi karena mereka bernapas dengan kecepatan yang lebih tinggi daripada orang dewasa

Ada dugaan kuat bahwa pajanan ozon dan polutan udara lainnya pada masa-masa awal kehidupan, dalam jangka panjang dapat mengakibatkan inflamasi, kerusakan paru, serta perubahan yang menetap pada saluran napas dan jaringan paru. ${ }^{13}$ Masa-masa awal kehidupan, yaitu periode pre-natal dan post-natal hingga masa kanak-kanak, merupakan masa di mana terjadi tumbuh kembang sistem pernapasan yang paling pesat, sehingga terdapatnya pajanan yang intensif dari $\mathrm{PM}_{10}$, $\mathrm{NO}_{2}$, dan ozon pada masa tersebut akan memberikan dampak kerusakan yang bersifat jangka panjang. ${ }^{12}$

\section{Upaya Pengendalian Pencemaran Udara}

Program pengendalian pencemaran udara yang diupayakan oleh pemerintah Indonesia secara nasional adalah Program Langit Biru (PLB) yang dicanangkan pada tanggal 6 Agustus 1996 di Semarang oleh Menteri Negara Lingkungan Hidup. Program langit biru bertujuan mengendalikan pencemaran udara, khususnya yang bersumber dari sektor transportasi. Tujuannya adalah untuk mencapai kualitas udara ambien yang memenuhi standar kesehatan manusia dan makhluk hidup yang lain. Upaya pengendalian yang terkait dengan program tersebut antara lain adalah: pemantauan kualitas udara ambien, pengendalian pencemaran udara dari sarana transportasi. Hal tersebut meliputi penggunaan bahan bakar bersih, pengembangan manajemen transportasi, mengubah mesin kendaraan, dan memasang alat-alat pembersih polutan pada kendaraan, serta pemantauan emisi gas buang kendaraan bermotor. Selain itu, dilakukan upaya mempertahankan "paru-paru" kota dengan memperluas pertamanan dan penanaman berbagai jenis tumbuh-tumbuhan sebagai penangkal pencemaran udara. Terkait dengan pemantauan kualitas udara ambien, upaya tersebut telah dilakukan dengan pembangunan stasiun pemantau kualitas udara kontinyu, yaitu pembangunan 33 Stasiun Pemantau Kualitas Udara Permanen dan sembilan Stasiun Pemantau Kualitas Udara Bergerak di kota-kota di Indonesia sejak tahun 1999.

Dalam upaya pemantauan emisi gas buang kendaraan bermotor, terdapat satu program unggulan yaitu Program Emission Mandatory Disclosure of Automotive Emission. Program tersebut merupakan pemberlakuan dari Keputusan Menteri Negara Lingkungan Hidup No. 141/2003 tentang Ambang Batas Emisi Gas Buang untuk Kendaraan Bermotor Tipe Baru. Program ini dinilai sangat strategis untuk mengendalikan emisi gas buang dari kendaraan bermotor untuk jangka panjang. Keuntungan lain yang diharapkan dari program tersebut adalah terwujudnya self declaration dari pihak industri kendaraan bermotor yang memberikan customer pilihan untuk berbagai jenis kendaraan bermotor yang ramah lingkungan, sehingga akan terjadi kompetisi yang fair di antara industri kendaraan bermotor dalam menciptakan kendaraan yang akan mengarah pada konsep zero emission vehicle.

Pencemaran udara ambien di wilayah perkotaan di berbagai belahan dunia telah mengakibatkan dampak kesehatan yang merugikan, terutama terhadap sistem pernapasan. Anak-anak khususnya yang dengan riwayat asma merupakan kelompok yang paling banyak terkena dampak. Polutan udara ambien yang menjadi fokus perhatian terkait gangguan dan penyakit pernapasan adalah ozon, oksida nitrogen, dan partikulat yang respirabel. Sumber utama ketiga jenis polutan tersebut adalah dari 
emisi kendaraan bermotor. Sejumlah penelitian yang telah dilakukan terhadap anak-anak yang tinggal di pemukiman yang dekat dengan jalan raya memperlihatkan hasil yang konsisten bahwa anak-anak tersebut berisiko lebih besar untuk menderita berbagai penyakit pernapasan. Hal tersebut meliputi kasus asma baru, peningkatan gejala asma ataupun eksaserbasi asma, absensi yang tinggi, serta rawat inap akibat asma yang tinggi. Populasi besar anak-anak yang terpajan polutan udara ambien pada level yang tinggi dan risiko kejadian dampak kesehatan yang merugikan, hingga kini belum menjadi fokus perhatian penurunan kasus gangguan pernapasan, khususnya asma. Berbagai bukti penelitian menunjukkan hubungan yang signifikan antara polusi udara yang bersumber emisi kendaraan bermotor dengan dampak kesehatan yang merugikan, maka pemerintah perlu melakukan upaya penurunan polusi udara.

Langkah kebijakan Indonesia terkait dengan pengendalian pencemaran udara yang diambil oleh pemerintah adalah Program Langit Biru, yang telah dicanangkan secara nasional sejak tahun 1996. Walaupun pencanangan Program Langit Biru telah dilakukan sejak tiga belas tahun yang lalu, namun pelaksanaan program melalui kegiatan riil baru terwujud beberapa tahun kemudian. Pada tahun 2000 pemerintah mulai mengoperasikan jaringan pemantau kontinyu otomatis di 10 kota, yaitu Jakarta, Bandung, Denpasar, Jambi, Medan, Palangkaraya, Pekanbaru, Pontianak, Semarang, dan Surabaya. Pemantauan kualitas udara tersebut dilakukan oleh beberapa lembaga pemerintah untuk berbagai tujuan, meliputi pemantauan konsentrasi $\mathrm{CO}, \mathrm{SO}_{2}, \mathrm{NO}_{\mathrm{x}}$, $\mathrm{O}_{3}$ dan debu $\left(\mathrm{PM}_{10}\right)$. Data yang diperoleh dari pemantauan ini dipergunakan untuk menghitung Indeks Standar Pencemar Udara (ISPU) dan ditampilkan pada papan display ISPU yang tersebar di beberapa lokasi di dalam kota.

Selain pemantauan kualitas udara, upaya lain dalam Program Langit Biru juga seharusnya dilaksanakan. Akan tetapi, pelaksanaan Program Langit Biru tidak serentak dilakukan oleh tiap daerah karena bergantung pada kesiapan daerah masing-masing. Jakarta, sebagai salah satu kota dengan tingkat polusi tertinggi, baru tahun 2006 melaksanakan Program Langit Biru untuk mengendalikan emisi gas buang dari kendaraan, khususnya mobil pribadi. Pelaksanaan emisi bersih tersebut masih terhambat antara lain oleh ketidaksiapan bengkel dalam melakukan uji emisi, pengadaan stiker tanda lulus uji emisi terhalang oleh birokrasi yang berbelit-belit, serta kekhawatiran adanya pemalsuan stiker. ${ }^{14}$ Kendala lainnya dalam pelaksanaan Program Langit Biru adalah sebagai berikut, ${ }^{15}$ program tidak efektif karena pemerintah tidak serius mengawal pelaksanaan program. Pemerintah dianggap hanya berusaha membangun citra "peduli pencemaran udara”. Tidak ada peraturan yang lebih ke- tat terkait dengan pelaksanaan program, tidak ada keselarasan antara kebijakan pembangunan dengan tata ruang kota (untuk mempertahankan ruang terbuka hijau), perusahaan otomotif masih memproduksi kendaraan dengan teknologi usang yang tidak ramah lingkungan karena harga lebih terjangkau pasar. Dengan berbagai kendala tersebut, tentu kontribusi Program Langit Biru terhadap penurunan kasus gangguan pernapasan pada anak belum dapat diperkirakan. Padahal kasus-kasus penyakit yang terkait dengan gangguan pernapasan pada anak masih selalu menempati posisi teratas dari 10 penyakit terbanyak di puskesmas-puskesmas di berbagai kota di Indonesia.

Berdasarkan sejumlah penelitian yang dilakukan di beberapa kota di dunia, kebijakan pengendalian pencemaran udara dapat berkontribusi yang secara memadai menurunkan kasus penyakit pernapasan pada anak, terutama asma. Gilliland, 2 mengemukakan bahwa penurunan tingkat polusi udara hingga ke level yang terbaik memberikan dampak yang besar bagi pemukiman. Dampak tersebut antara lain meliputi: (1) Angka kunjungan tahunan terkait asma ke unit gawat darurat di rumah sakit dan angka rawat inap asma menurun dari 22\% menjadi 6\%. (2) Prevalensi bronchitis menurun dari 40\% menjadi 20\%. (3) Angka absensi sekolah terkait asma menurun hingga dua pertiga. (4) Kasus baru asma menurun hingga $75 \%$.

Dengan demikian, pelaksanaan Program Langit Biru seharusnya mendapatkan dukungan yang penuh dari pemerintah serta partisipasi yang tinggi seluruh lapisan masyarakat. Dengan demikian, dapat segera tercapai kondisi penurunan pencemaran udara hingga ke tingkat yang aman bagi kesehatan.

\section{Daftar Pustaka}

1. National Campaign for Healthy Environment. Udara kota. UAQ-i Newsletter. Edisi 1. [diakses tanggal 25 Desember 2009]. Diunduh dari: http://udarakota.bappenas.go.id/.

2. Gilliland FD. Outdoor air pollution, genetic susceptibility, and asthma management: opportunities for intervention to reduce the burden of asthma. Pediatrics. 2009. 123(Suppl 3): 168-73.

3. EPA. Airborne particulates. The State of Queensland: Environmental Protection Agency; 2006.

4. Blumenthal DS. Introduction to environmental health. $2^{\text {nd }}$ Edition. Springer Publishing Company: 1995.

5. Koren H. Handbook of environmental health. Biological, chemical, and physical agents of environmentally related disease. Volume 1. USA: Lewis Publishers; 2003.

6. Halliwell B. Oxygen-derived species: their relation to human disease and environmental stress. Environmental Health Perspectives. 1994; 102(Suppl 10): 5-12.

7. Rahman I. [edisi 2008, diakses tanggal 7 Oktober 2009]. Diunduh dari: www2.envmed.rochester.edu/.../irfan_rahman.html.

8. Balmes JR. Ozone: biology of human health effects [edisi 1993, diakses 
tanggal 7 Agustus 2009]. Diunduh dari: www.superfund.berkeley.edu/ pdfs/wf_balmes.pdf.

9. Villarreal AB. Air pollution, airway inflammation, and lung function in a cohort study of Mexico City schoolchildren. Environmental Health Perspectives. 2008; 116(6): 832-8.

10. Pinkerton KE. Influence of air pollution on respiratory health during perinatal development. Proceedings of the Australian Physiological Society: 2005.

11. Delfino RJ. Epidemiologic evidence for asthma and exposure to air toxics: linkages between occupational, indoor, and community air pollution research. Environmental Health Perspectives. 2002; 110(Suppl 4): 573-89.

12. Latzin $P$. Air pollution during pregnancy and lung function in newborns
: a birth cohort study. European Respiratory Journal. 2009; 33: 594-603.

13. Amann M. Health risks of ozone from long-range transboundary air pollution. Report prepared by the Joint WHO/Convention Task Force on the Health Aspects of Air Pollution. Europe: World Health Organization (WHO): 2008 . [diakses tanggal 16 Oktober 2009]. Diunduh dari: www.euro.who.int.

14. Program langit biru: pengadaan stiker lulus uji emisi jangan dipersulit. [edisi 5 November 2009, diakses tanggal 24 November 2009]. Suara Karya Online. Diunduh dari: http://www.suarakaryaonline.com/news.html?id=239228.

15. Bisnis kalahkan program langit biru. [edisi 30 Oktober 2009, diakses tanggal 24 November 2009]. Diunduh dari: http://www.greenradio.fm/. 